\title{
Phenotypic Characterization of Vibrio species: Application of Indigenous Phages for Biological Control of Vibrio in Aquaculture Live Feeds
}

\author{
Sahar Wefky Mostafa Hassan* \\ Marine Microbiology Department, National Institute of Oceanography \\ and Fisheries, Alexandria, Egypt \\ *Corresponding author
}

\begin{abstract}
A B S T R A C T
Twenty Vibrio species were isolated from different sites along Alexandria sea shore. The phenotypic characterization, haemolytic activity and resistance pattern of the isolated Vibrio strains to different commercial antibiotics were investigated. All isolates showed

Keywords

Vibrio spp., Vibriophages, Characterization, Biocontrol, Artemia salina.

Article Info

Accepted: 26 April 2017 Available Online: 10 May 2017 varied results in the biochemical and physiological tests. Count estimation of the associated vibriophages were carried out using the isolated Vibrio species (V1-V20) as host strains. The highest counts $(1840 \mathrm{PFU} / \mathrm{ml})$ was recorded on V17. Four morphologically distinct phages namely P10, P16, P17 and P20 were selected and tested for their host specificity to the isolated Vibrio strains. P17 showed the highest host specificity (55\%). The present study looks to sensitivity of P17 toward temperature, $\mathrm{pH}$ and ultraviolet radiation. Results concluded that $\mathrm{P} 17$ was sensitive to heat and the most destructive temperature was $5^{\circ} \mathrm{C}$ with $100 \%$ reduction in the phage titre. The highest lytic activity of p17 was at pH7, lower activity was observed at $\mathrm{pH}$ lower or higher than $\mathrm{pH} 7$. UV affected phage survival after 2 sec exposure, however low lytic activity was observed up to exposure to UV for120 sec. Phage host interaction showed that P17 had burst size (100 PFU per cell) and latent period (10 min). P17 was tested for its potentiality as biocontrol agent of Vibrio sp. in the live feed Artemia salina. P17 showed promising lytic activity against Vibrio sp. invading A. salina and recorded $92 \%$ reduction in Vibrio load after $18 \mathrm{~h}$, which can be applicable as ecofriendly bio control agent of pathogens in the aquaculture.
\end{abstract}

\section{Introduction}

Bacterial infection is a significant threat to mankind. Many forms of human illness as a result of bacterial infection are common, with Vibrio species. Vibrios are one of the most common ubiquitous bacteria in the aquatic environment, they occur in commensal or symbiotic associations with eukaryotic organisms (Thompson et al., 2004).

They naturally found in coastal, estuarine and marine environment world wide

(Letchumanan et al., 2014; Raghunath, 2014). Vibrionaceae have primarily been investigated due to their pathogenic potential to humans and aquatic animals and can be transmitted to humans via infected water or through fecal transmission. Several species of Vibrio have been implicated with disease in fishes (Elhadi et al., 2004; Ran and Su, 2006; $\mathrm{Su}$ and Liu, 2007) and shrimp causing high mortality and serious loss in prawn hatcheries (Ruangpan and Kitao, 1991). 
The presence of this bacterium in the marine environment raises the concern of human on food safety due to the latter potential in causing disease outbreaks depending on the environmental conditions (Ceccarelli et al., 2013).

There are many different used antibiotics for treatment for Vibrio species infections (Han et al., 2007; Al-Othrubi et al., 2014). Our dependence on antibiotics to control bacterial infections in agriculture, aquaculture, veterinary medicine and humans resulted to indiscriminate use which in turn led to the emergence of multidrug resistant strains in the biosphere (Rao and Lalitha, 2015; (Letchumanan et al., 2015; Shrestha et al., 2015; Zavala Norzagaray et al., 2015).

Development of novel non-antibiotic approach to fight against bacterial infections (Rice, 2008; Freire-Moran et al., 2011) is needed. Recently, interest in the application of bacteriophage to control bacterial infections in various fields including agriculture, veterinary, food safety and human infections has been renewed (Meaden and Koskella, 2013; Payet and Suttle, 2014; Wittebole et al., 2014).

Early discovery of bacteriophages as antibacterial agents were reported in 1896 after observing antibacterial properties of this viral like agent against Vibrio cholerae in Ganges River, India (Adhya and Merril, 2006).

Therefore, the present study aims to isolate, characterize different Vibrio species and their associated phages and provides an insight into Vibriophages and their interaction with their Vibrio host species. Moreover, bacteriophage application in controlling Vibrio species in Artemia salina before their administration to fish larvae will be investigated.

\section{Materials and Methods}

\section{Sampling}

Water samples were collected from different sites of Alexandria sea shore, Egypt, in a sterile screw capped bottles, transferred to laboratory in ice box according to APHA (1998) and stored at $4^{\circ} \mathrm{C}$ till analysis.

\section{Culture media}

All culture media which were used for isolation were of pure grade and purchased from Difco, Detroit, USA, and prepared according to the manufacturer's instructions.

\section{Isolation of Vibrio species}

Water samples were diluted up to $10^{-5}$ with sterile sea water., spread on TCBS (Thiosulfate Citrate Bile Salts Sucrose) agar plates, and incubated at $30^{\circ} \mathrm{C}$ for $48 \mathrm{~h}$. Representative colonies were picked and transferred onto marine agar (MA; BD Difco) plates for further purification and taxonomic studies (Abou-Elela et al., 2009a )

\section{Phenotypic characterization}

Twenty Vibrio isolates were picked from TCBS agar plates according to their colony morphology, size, and pigmentation variability and examined for some morphological characters on nutrient agar after $24 \mathrm{~h}$. Physiological and biochemical tests such as temperature in the range of $10-40^{\circ} \mathrm{C}$ were studied. Tolerance to $\mathrm{NaCl}$ was determined by the addition of $\mathrm{NaCl}$ with 6,8 and $10 \%$. A number of conventional biochemical tests were carried out on all isolates, including sugar fermentation, urease, catalase, gelatinase and indole production, degradation of agar, starch, casein. Antimicrobial test was carried out according to El-Masry et al., (2002). 


\section{Haemolytic activity}

Haemolytic activity was performed using human blood agar plates $5 \%(\mathrm{v} / \mathrm{v})$. Positive result was indicated as clear zone of haemolysis around the colony (Brender and Janda, 1987).

\section{Antibiotic susceptibility test}

Resistance of the isolated Vibrio species were tested against different antibiotics (imipenem, $10 \mu \mathrm{g}$; ampicillin, $10 \mu \mathrm{g}$; norfloxacin $10 \mu \mathrm{g}$; cephalexin, $30 \mu \mathrm{g}$; erythromycin, $15 \mu \mathrm{g}$; flucloxacillin, $5 \mu \mathrm{g}$; ciprocin $5 \mu \mathrm{g}$ and chloramphenicol, $5 \mu \mathrm{g}$, by disk diffusion method (Bauer et al.,1966). Selected antibiotic discs were placed on Mueller Hinton Agar (HiMedia, India) (with 2\% $\mathrm{NaCl}$ ) plates seeded with bacteria. These plates were then incubated at $37^{\circ} \mathrm{C}$ for 24 hours. The organisms were observed for antibiotic sensitivity based on diameters of zones of inhibition on the Petri dishes.

\section{Estimation of phage counts infecting Vibrio species}

Double agar layer technique (DAL) described by Adams (1959) was used for phage detection and enumeration. One $\mathrm{ml}$ of the water sample or appropriate dilution of the sample and $0.2 \mathrm{ml}$ of exponentially growing host culture were added to $3 \mathrm{ml}$ of liquefied soft agar. The mixture was poured onto Petri dishes containing nutrient agar medium, allowed to solidify and incubated at $30^{\circ} \mathrm{C}$. The plaques were counted following 16-18 hours incubation.

\section{Isolation, propagation and purification of bacteriophages}

Bacteriophages specific to the isolated Vibrio strains were isolated from seawater samples using a double-agar-layer method (Adams, 1959). The plates were incubated overnight at $25^{\circ} \mathrm{C}$ for plaque formation. If plaques were detected, a single plaque was picked from the plate using a sterile Pasteur pipette tip and eluted into $1 \mathrm{~mL}$ of exponential phase culture of the respective Vibrio strain. The mixture was plated on semi-solid agar medium again for plaque formation. The procedure was repeated three times for phage purification. Purified phages were stored in SM buffer (50 $\mathrm{mM}$ Tris- $\mathrm{HCl}, \mathrm{pH} 7.5,99 \mathrm{mM} \mathrm{NaCl}, 8 \mathrm{mM}$ $\mathrm{MgSO}_{4}, 0.01 \%$ gelatin) at $4{ }^{\circ} \mathrm{C}$.

\section{Determination of phage titre}

Titers of phage suspensions were determined by serial dilution in SM buffer followed by a drop count method. One milliliter of exponential phase bacterial culture was mixed with $5 \mathrm{~mL}$ of warm soft nutrient agar and then poured over presolidified nutrient agar plates to prepare semi-solid agar plates. Five $\mu 1$ drops of each phage suspension dilution were inoculated on the surface of semisolid agar plates (Yu et al., 2013).

The inoculated plates were incubated overnight at $25^{\circ} \mathrm{C}$ for plaque formation. All treatments were performed in triplicates. The number of plaques in each drop was recorded, and tires of phage suspensions were defined as plaque-forming units (PFU/ml).

\section{Determination of lysis spectrum of the isolated bacteriophages}

All the isolated Vibrio species were used for determination of lysis spectrum of the isolated bacteriophage. Briefly, $5 \mu \mathrm{l}$ of each isolated phage were spotted on each agar plate with different Vibrio strains. The plates were incubated at $25{ }^{\circ} \mathrm{C}$ overnight and examined for the appearance of plagues (Taj et al., 2014).

\section{Electron microscopy examination}

A suitable volume of concentrated bacteriophage sample was deposited on a Formvar-carbon-coated copper grid. The 
samples were negatively stained with $2 \%$ sodium phosphotungstate $(\mathrm{pH} 7.6)$ and then examined with JEOL $100 \mathrm{CX}$ transmission electron microscope (TEM) operating at 80 $\mathrm{kV}$ at Faculty of Science, Alexandria University (Stenholm et al., 2008).

\section{Heat sensitivity}

The thermal stability of phages was examined by pre incubating phage suspensions at different temperatures $(5,30,50,70$ and $100^{\circ} \mathrm{C}$, respectively) at $\mathrm{pH} 7$ for $2 \mathrm{~h}$. The phage suspensions were immediately cooled in ice water, and the surviving phages were estimated by the double-agar layer method (Basdew and Laing, 2014).

\section{pH sensitivity}

The $\mathrm{pH}$ stability of phage was examined by pre-incubating the phage suspensions at different $\mathrm{pH}$ levels $(4,7,9,11$, respectively) at $30^{\circ} \mathrm{C}$ for $2 \mathrm{~h}$. The surviving phages were immediately estimated by the double-agar layer method (Basdew and Laing, 2014).

\section{Ultraviolet irradiation sensitivity}

Sensitivity of phage isolate to ultra violet irradiation was done at a distance of $30 \mathrm{~cm}$ from a 15 Watt sterile lamp for different time intervals. Survival of phage isolate was determined at each time interval using the double-agar layer (Hassan, 2002).

\section{Statistical analysis}

Data analysis was performed with the software package Microsoft Excel, Version 2003. Statistically significant difference was determined using paired Student's t-test and $\mathrm{P}<0.001$ was used as a limit to indicate statistical significance.

\section{One-step growth curve (phage-host interaction)}

One-step growth curve experiments were adapted from Adams (1959) with modifications to determine the latent time and phage burst size. Phage suspension was mixed with $1 \mathrm{~mL}$ of exponential phase culture of $V$. parahaemolyticus and incubated at $25^{\circ} \mathrm{C}$ for $10 \mathrm{~min}$ for phage adsorption. The mixture was centrifuged at $10000 \mathrm{~g}$ for $10 \mathrm{~min}$ to remove free phage particles. The pellet was suspended in $60 \mathrm{~mL}$ of broth, and the culture was continuously incubated at $25^{\circ} \mathrm{C}$. Samples were taken at 10 min intervals upto $2 \mathrm{~h}$, and phage titer was determined (Yu et al., 2013).

\section{In vivo administration of phage in A.salina culture}

The brine shrimp, Artemia is a zooplanktonic organism widely used as live feed. It can be hatched within 24 hours from dormant cysts (batch culture) which can be easily distributed and stored for prolonged periods of time. Plastic containers were used, each containing $1 \mathrm{~L}$ of $A$. salina cultures supplied with intense aeration. A. salina was dosed with phage P17 $\left(10^{11} \mathrm{PFU} / \mathrm{ml}\right)$ while the control kept without phage inoculation. The total presumptive Vibrio count in each container was assessed at different time intervals, following serial dilutions of $1 \mathrm{ml}$ samples and plating in TCBS. The experiment was done in triplicates (Kalatzis et al., 2016).

\section{Results and Discussion}

\section{Isolation and phenotypic characterization of Vibrio spp.}

Vibrio spp. occurs naturally in aquatic environments and are one of the most commonly-occurring bacteria during shrimp farming (Vandenberghe, et al, 2003). The number of reported Vibrio species increased rapidly in the last decade (Thompson, et al., 2004). Vibrio species have been associated with skin infections and severe gastrointestinal disorders (Andrews, 2004). In the present study, among the isolated Vibrio 
spp., twenty isolates were selected according to difference in size, colony morphology and pigmentation. They were subjected to morphological, physiological and biochemical characterization (Table 1). According to the tested characters, all the isolated Vibrio species were grouped into 3 phena.

\section{Phenon A}

This phenon contained 4 strains. They grew well at temperature range $\left(30-40{ }^{\circ} \mathrm{C}\right)$ but without growth at $10{ }^{\circ} \mathrm{C}$ and $20^{\circ} \mathrm{C}$. All strains grew at $6,8 \% \mathrm{Na} \mathrm{Cl}$ while only two grew at $10 \%$. They were able to utilize glucose, fructose and sucrose as carbon source, moreover they had capability to produce catalase, urease and gelatinase, but no indole production or nitrate reduction. They were able to degrade starch only. Antibacterial activity was observed against all tested bacterial pathogens except for $P$. aeruginosa and $V$. anguillarum.

\section{Phenon B}

This phenon harbored 4 strains, they are characterized by well growth at temperature range $\left(30-40{ }^{\circ} \mathrm{C}\right)$. All strains grew at $6 \%$ $\mathrm{NaCl}, 75 \%$ of the tested strains were able to grow at 8 and $10 \% \mathrm{NaCl}$. No indole production or nitrate reduction. They were fermenters of glucose and sucrose but no fermentation of fructose. They exhibited the ability to degrade starch and casein. All isolates showed antibacterial potentiality against the tested pathogens except for $V$. anguillarum.

\section{Phenon C}

This phenon was the major one and contained twelve strains. All strains grew at temperature $\left(30-40{ }^{\circ} \mathrm{C}\right) .75 \%$ of the tested strains grew at 6 and $8 \% \mathrm{NaCl}$, while only $50 \%$ were able to grew at $10 \%$. Contrarely to phenon $\mathrm{A}$ and $\mathrm{B}$, all the tested Vibrio species in phenon $\mathrm{C}$ were positive for indole production and nitrate reduction. They are fermenters of glucose and fructose, only $92 \%$ are sucrose fermenters. Varied percentages of antibacterial activity were detected against the tested pathogenic bacteria with no antibacterial activity against $P$. florescence, $P$. aeruginosa, $V$. anguillarum and E. coli.

Taxonomic study of Vibrio spp. was previously reported in different studies (Noriega-Orozco et al., 2007, Abou-Elela, et al., 2009b; Ganesh et al., 2012).

\section{Haemolytic activity}

Haemolytic activity of the isolated Vibrio species was tested on human blood agar. Results in table 2 revealed that haemolysis of human blood were detected in 12 isolates representing about $60 \%$ of the isolated strains.

\section{Antibiotic resistance of the haemolytic Vibrio spp.}

Variation in the in vitro susceptibility of Vibrio to antibiotics has been observed, with emerging resistance to nalidixic acid, cotrimoxazole, furazolidone and streptomycin. The emergence of multidrug-resistant strains has been a matter of concern (Mahbub et al., 2011). The presence of multiple antibiotic resistances in isolates that are not recognized as pathogens is also extremely important, as this indicates that commensal or environmental bacteria can serve as reservoirs for resistance genes.

In the present study, The haemolytic Vibrio spp. were screened for the sensitivity to some commercial antibiotics including imipenem, $10 \mu \mathrm{g}$; ampicillin, $10 \mu \mathrm{g}$; norfloxacin,10 $\mu \mathrm{g}$; cephalexin, $30 \mu \mathrm{g}$; erythromycin, $15 \mu \mathrm{g}$; flucloxacillin, $5 \mu \mathrm{g}$; ciprocin, $5 \mu \mathrm{g}$, and chloramphenicol, $5 \mu \mathrm{g}$. As shown in table 3 out of the tested 12 strains, eight strains were resistant to 


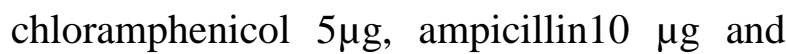
erythromycin, $15 \mu \mathrm{g}$ which represented the highest resistance percentage $(67 \%)$. On the other side, flucloxacillin, $5 \mu \mathrm{g}$ was the most effective against about $58 \%$ of the tested strains. Different degree of resistance was observed for the other tested antibiotics which agree with that reported by Abou-Elela et al., 2009a. In comparative study, Mahbub et al (2011) studied the antibiotic resistance pattern of fifteen Vibrio spp. isolated from shrimp rearing ponds in Bangladesh and it was shown that the highest resistance was to ampicillin (100\%), followed by amoxicillin (78\%), nalidixic acid (40\%), vancomycin (13.33\%), neomycin $(6.66 \%)$ and chloramphenicol (6.66\%). Similar observation was reported by Ransangan et al., (2013) where approximately $78 \%$ of the environmental Vibrio isolates were found to be resistant to ampicillin. Similarly, Manjusha et al., (2005) reported that environmental Vibrio isolates were the most resistant to ampicillin and all the isolates were observed as sensitive to gentamycin, erythromycin, ciprofloxacin and doxycycline. Ransangan et al., (2013) reported the sensitivity of all tested Vibrio spp. to chloramphenicol.

\section{Diversity of Vibriophages in the selected water samples}

Successful application of phage therapy in the treatment of Vibriosis requires detailed knowledge of the diversity and distribution of the associated phages and susceptibility properties of Vibrio species as well as a collection of well-characterized phages that covers host diversity (Taj et al., 2014).

In the present study, diversity of the indigenous phages infecting Vibrio spp. was studied in the collected samples. All the isolated Vibrio species (V1-V20) were used as host culture for detection and estimation of phage counts in the selected samples. As shown in figure 1, the counts of Vibrio phages ranged from $4 \times 10$ to $184 \times 10 \mathrm{PFU} / \mathrm{ml}$. The highest count $(184 \times 10 \mathrm{PFU} / \mathrm{ml})$ were detected on V17 and recorded as the most sensitive strain to Vibriophages followed by V16 which recorded 56x10 PFU/ml, while the lowest count was detected on V4 with only 40 $\mathrm{PFU} / \mathrm{ml}$. On the other side, no estimates of bacteriophages were detected on V1, V5, V6, V7, V8, V9, V11, V12 and V15.

\section{Determination of the lysis spectrum of the isolated bacteriophages}

Among all isolated phages, four morphologically distinct Vibriophages namely P10, P16, P17 and P20 were selected and tested for their lytic capability or specificity toward all the isolated Vibrio spp using spot assay method. As shown in table 4, P10 showed narrow range of host specificity and exhibited lytic activity against only V2, V4, V15, V16 and V10, which represented $25 \%$ of the tested Vibrio species. Also V16 and V20 showed narrow range of host specificity with 5 and $30 \%$ infection capability, respectively. Narrow range of host specificity can be explained by the fact that most of the marine phages are specific and lyse only the original host bacterium as was described by Hassan, 2011. On the other side, P17 showed broader lytic capability and host range where it was able to infect V2,V4, V8,V9, V10, V12, V14, V15, V16, V17 and V20 which represented $55 \%$ of the tested Vibrio species and was not limited to the host strain, The most sensitive bacterial isolate V17 was selected to complete the study and identified as Vibrio parahaemolyticus by using API 20 Kit. Vibrio parahaemolyticus is a halophilic gramnegative bacterium that is widely distributed in coastal waters worldwide and is associated with wound infections, gastroenteritis, and septicemia (Daniels et al., 2000). Occurrence of $V$. parahaemolyticus infections are reported to occur due to direct contact with estuarine waters or the consumption of undercooked raw shellfish (Lin and Lin, 
2012). V. parahaemolyticus pandemic strains have displayed multiple antibiotic resistances, increasing concerns about possible treatment failure. Yu et al., (2013) studied the host range of five isolated Vibrio phages (P3K; P4A; P7A; P8D; P9C) against different Vibrio strains isolated from sea water samples and reported that most of the Vibrio host strains lost their sensitivity against these five phages. So, the highest resistance with 97\% was against phage $\mathrm{P} 9 \mathrm{C}$ and the lowest resistance was found with $41 \%$ against phage $\mathrm{P} 3 \mathrm{~K}$. This lytic spectrum could be explained by the conservative nature of the structure of phage receptors on the outer membrane of many of Gram negative bacterial species (Rakhuba et al., 2010). Regarding the host specificity of VP17, it was selected for more detailed studies of phage lytic potential and phagehost interactions.

\section{Characterization of P17}

\section{Electron microscopic examination}

The electron micrograph of P17 is illustrated in Figure 2. Based on particle morphology, P17 belonging to order Caudovirales, and family Podoviridae which is characterized by icosahedral capsid and short tail. To date, most of the marine viruses reported are bacteriophages that belong to order Caudovirales (Rao and Lalitha, 2015, Letchumanan et al., 2016). Podoviruses were previously isolated from marine environment (Jiang et al., 1998; Sun et al., 2014; Zhan et al., 2016). Figure 3 represents the shape of plaques produced by phage P17 on the host bacterium ( $V$. parahaemolyticus). As shown, the plaques were of about $3 \mathrm{~mm}$ diameter with clear center

\section{Heat sensitivity}

Temperature is one of the most important environmental factors that strongly affect many aspects of the biological systems.
Influence of changes in temperature regimes on the biological system is very vivid and affects the species distributions, evolution of phenotypic traits (Vale et al., 2008). P17 was exposed to different temperature for a period of $2 \mathrm{~h} \mathrm{~min}$ before addition to the host bacterium. The counts of P17 were estimated each time by the use of DAL. Significant differences were noted between phage activity at each temperature $(\mathrm{P}<0.001)$, p17 was sensitive to temperature and its sensitivity increased by increasing temperature, however it still active even after boiling, the optimum temperature for bacteriolytic activity was $3 \times 10^{8} \mathrm{PFU} / \mathrm{ml}$ at $30{ }^{\circ} \mathrm{C}$ (Figure 4). Overall results show that propagation of these phages is negatively affected by increased exposure to high temperatures and the most damaging temperature was $5{ }^{\circ} \mathrm{C}$ with $100 \%$ reduction in phage titers followed by reduction of phage counts to $97 \times 10^{5} \mathrm{PFU} / \mathrm{ml}$ up on exposing to $50^{\circ} \mathrm{C}$. This result is encouraged by study of Jun et al., (2014) who observed that $\mathrm{pVp}-1$ phage specific to $V$. parahaemolyticus was relatively heat stable over a temperature range of $20^{\circ} \mathrm{C}-37^{\circ} \mathrm{C}$, although decrease in phage activity was detected at $50^{\circ} \mathrm{C}$ and complete loss of activity was at $65^{\circ} \mathrm{C}$. Basdew and Laing (2014) reported that increase in temperature decreases virus survival and activity and exposure to $70^{\circ} \mathrm{C}$ was the most damaging with a 92 to $96 \%$ reduction in phage titers. In the same way, findings by Pope et al., (2004) indicated an increase in bacteriophage yield till $30^{\circ} \mathrm{C}$ and $39^{\circ} \mathrm{C}$ which corroborates the present study. Lal et al., (2016) isolated VpKK5 as specific phage to $V$. parahaemolyticus and found that it was stable at $40{ }^{\circ} \mathrm{C}$ and declined at $50{ }^{\circ} \mathrm{C}$ following heating for $60 \mathrm{~min}$, moreover the activity was disappeared entirely when heated at more than $60^{\circ} \mathrm{C}$ for $1 \mathrm{~h}$.

\section{pH sensitivity}

$\mathrm{pH}$ is an important factor which make changes in the protein of the tail region of the 
phage particle and could affect the adsorption of the phage to the bacterial wall, thus inactivating the phage particle (Seeley and Primrose, 1982). ANOVA showed highly significant differences $(\mathrm{p}<0.001)$ between phage titres treated with different $\mathrm{pH}$ ranges. The present study (Figure 5) concluded that $\mathrm{pH} 7$ was the most suitable for bacteriolytic activity of $\mathrm{P} 17$ which recorded $3 \times 10^{8} \mathrm{PFU} / \mathrm{ml}$ followed by $\mathrm{pH} 9$ with $1 \times 10^{7} \mathrm{PFU} / \mathrm{ml}$, however low stability of P17 is still present until $\mathrm{pH} 11$ which recorded $2 \times 10^{4} \mathrm{PFU} / \mathrm{ml}$. On the other hand, low $\mathrm{pH} 4$ caused reduction in the phage counts to $2 \times 10^{5} \mathrm{PFU} / \mathrm{ml}$. $\mathrm{pH}$ finding of the study was confirmed by Langlet et al., (2007) and Ibrahim et al., (2017) who indicated that virus exhibited stability at wide range of $\mathrm{pH}$ regimes. The same finding was reported by Taj et al., 2014.

In accordance with the present study, $\mathrm{pH} 6$ to 7 was reported for optimal phage replication, followed by a sharp decline at higher $\mathrm{pH}$ (Basdew and Laing, 2014). This was also noted in a study by Da Silva and Janes (2005), where phages specific to Vibrio spp. (infective on oysters) were screened at various $\mathrm{pH}$ ranges (6-7) and it was noted that Vibrio phages were most stable at that $\mathrm{pH}$ range which best mimicked the $\mathrm{pH}$ of the oyster system. Lal et al., (2016) reported that the activity of the Vibrio phage VpKK5 was measurable after incubation at $\mathrm{pH}$ 4-9, but completely disappeared at $\mathrm{pH} 2$ and $\mathrm{pH} 3$.

\section{UV sensitivity}

Ultraviolet radiation as a mean of reducing microorganisms is gaining more importance both in the treatment of certain drinking water and in advanced treatment of wastewater (Zukovs et al., 1986). As observed in Figure 6, P17 was affected by the exposed UV and the phage titre was reduced to $4 \times 10^{5}$ after 2 sec, and the counts reduced with increasing the time of exposure to reach $3 \times 10^{3}$ after 60 min., however the phage is still having bacteriolytic activity with $2 \times 10^{5} \mathrm{PFU} / \mathrm{ml}$ until exposure to $120 \mathrm{sec}$. ANOVA showed highly significant differences $(\mathrm{p}<0.001)$ between phage titres treated with UV for different time intervals. Hassan, (2002) reported that some isolated bacteriophages were stable upon exposure for $30 \mathrm{sec}$. but complete activation was observed at 60 and $120 \mathrm{sec}$. Studies on $\lambda$ phage (Wiegle, 1953) reported the inactivation of a large proportion of the phages upon exposure for $60 \mathrm{sec}$ and a high frequency of mutation in the surviving phage particles. Time required for the $37 \%$ survival of the $V$. cholera S20 phage was 7 sec. Around $80 \%$ phage particles were inactivated within $10 \mathrm{sec}$ of exposure to UV and only $10 \%$ survival was at $16 \mathrm{sec}$ as was reported by Dutta and Ghosh, 2007. A complete inactivation of $V$. parahaemolyticus phage Vp-1 was approximately at 45 mins upon exposure to UV light, as was observed by Jun et al., 2014.

\section{Phage-host interaction}

Phage host interactions are essential requirements for phage applications (Tan et al., 2014). Life cycle characteristic was determined for phage P17 from one-step growth curve during incubation with $V$. parahaemolyticus. As shown in figure 7, P17 exhibited the burst size (100 PFU per cell) and latent period (10 min). Phages with high burst size are the most appropriate candidates for phage therapy. Thus, P17 can be considered as good candidates for phage therapy applications since it has relatively high burst size compared to studies of Phumkhachorn and Rattanachaikunsopon, (2010) who reported that the latent period of the Vibrio phage PW2 was 30 min and it has a burst size of 78 PFU per infected cell. Lin et al., (2012) stated that he burst size of phage A318 infecting $V$. alginolyticus was 72 PFU per infected cell. Short latent period of approximately 15 min with a burst size of 47 $\mathrm{PFU} /$ cell was for $V$. parahaemolyticus phage Vp-1 as was stated by Jun et al., 2014. On the 
other side, Lal et al., (2016) reported that the latent period of the Vibrio phage VpKK5 was 36 min with $180 \mathrm{PFU}$ per infected cell as burst size. Another study recorded long latent periods $(150$ and $180 \mathrm{~min})$ for two bacteriophages isolated from the North Sea (Chan et al., 1966). Børsheim (1993) suggested that there is great variation in burst size; the average marine phage burst size range from 5 to 610 and the latent periods may increase to 170 and $120 \mathrm{~min}$ as was stated by Zachary, 1978. It can be concluded that the burst size and latent period of P17 isolate fell within the documented range for marine phages.

\section{In vivo efficacy of P17 to control Vibrio load in A. salina culture}

Increase of the pathogen load could increase the possibilities of disease outbreak in aquaculture. Effective prevention strategies will be essential in reducing disease burden due to bacterial infections (Yen et al., 2017). Reducing and controlling of Vibrios in fish and invertebrates hatcheries is critical for the survival and quality of the produced larvae. Live feed organisms like Artemia are able to bio-accumulation of bacteria from the water column acting as a vehicle for pathogen transfer into the hatchery facilities. Currently, the need of an innovative and environmentally friendly alternative to antibiotics has become more than necessary. Presence of bacteriophages in environments with pathogenic bacteria is an opportunity for development of a successful innovative and environmentally friendly solution for the prevention of multi-drug resistant bacteria spreading in aquaculture (Nakai and Park, 2002).

Fig.1 Counts of vibriophages on the isolated Vibrio species (host bacteria)

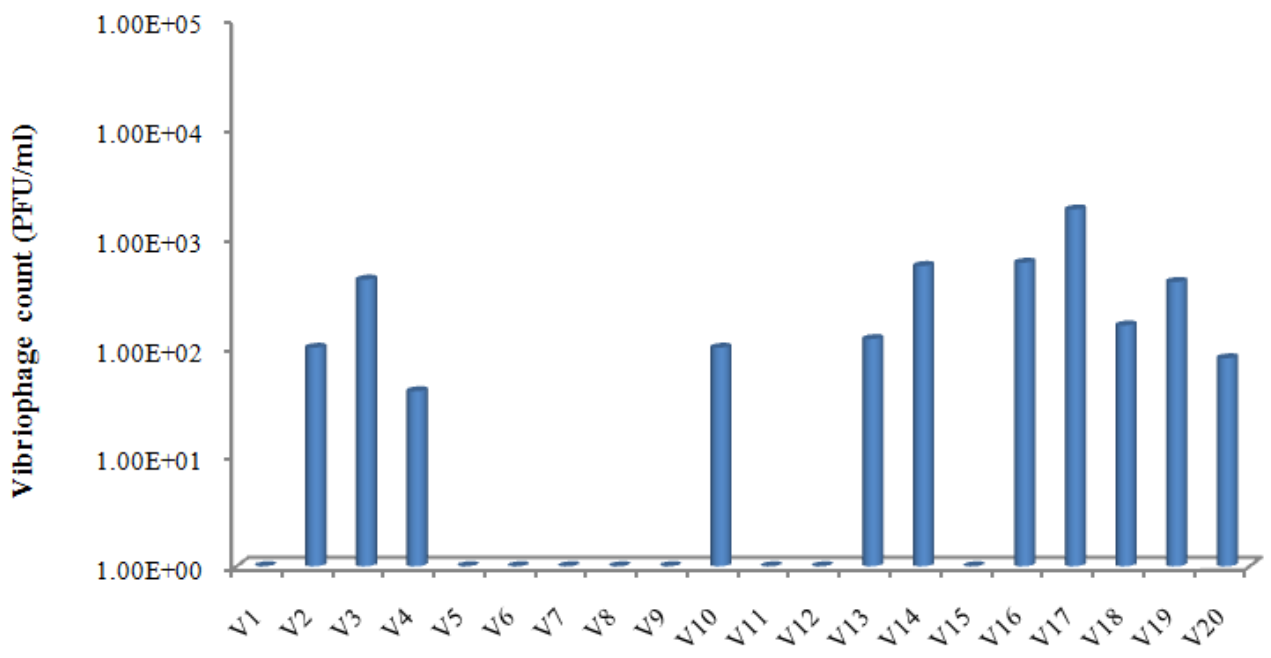

Vibrio isolates 
Table.1 Phenotypic characterization of the isolated Vibrio spp

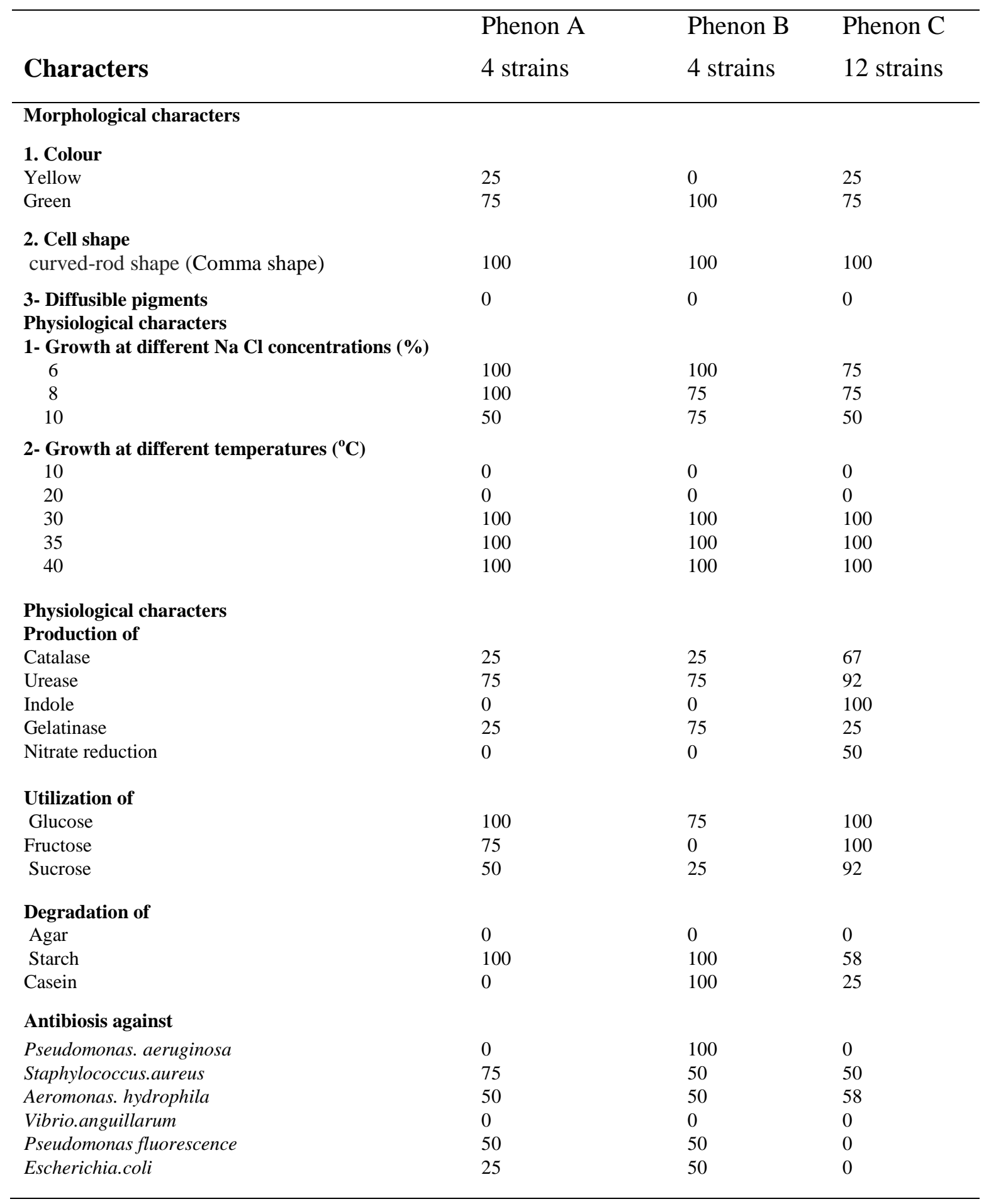


Table.2 Haemolytic activity of the isolated Vibrio spp

\begin{tabular}{cc}
\hline Vibrio isolates & Haemolysis \\
\hline V1 & + \\
V2 & + \\
V3 & + \\
V4 & + \\
V5 & + \\
V6 & + \\
V7 & + \\
V8 & + \\
V9 & + \\
V10 & - \\
V11 & - \\
V12 & - \\
V13 & - \\
V14 & - \\
V15 & - \\
V16 & + \\
V17 & + \\
V18 & - \\
V19 & + \\
V20 & - \\
\hline
\end{tabular}

Table.3 Resistance of the haemolytic Vibrio isolates to different commercial antibiotics

\begin{tabular}{llcccccccccccc}
\hline Tested antibiotics & \multicolumn{10}{c}{ HaemolyticVibrio isolates } \\
\cline { 2 - 11 } & V1 & V2 & V3 & V4 & V5 & V6 & V7 & V8 & V9 & V16 & V17 & V19 \\
\hline Chloramphenicol,5 $\mu \mathrm{g}$ & + & - & - & + & - & + & + & + & + & + & + & - \\
Flucloxacillin,5 $\mu \mathrm{g}$ & - & - & - & + & - & - & + & + & + & + & - & - \\
Ciprocin, 5 $\mu \mathrm{g}$ & + & - & - & + & + & + & + & - & + & - & - & - \\
Ampicillin, $10 \mu \mathrm{g}$ & + & + & - & + & + & + & + & - & + & - & - & + \\
Cephalexin, $30 \mu \mathrm{g}$ & + & - & - & + & + & + & + & - & + & - & - & - \\
Erythromycin, $15 \mu \mathrm{g}$ & + & - & - & + & + & + & + & + & + & - & - & + \\
Norfloxacin, $10 \mu \mathrm{g}$ & + & - & - & + & + & - & - & + & + & + & + & - \\
Imipenem,10 $\mu \mathrm{g}$ & - & + & + & + & + & - & + & + & + & - & - & - \\
\hline
\end{tabular}

+: Resistance; -: Sensitivity 
Table.4 Host range of Vibrio phages P10, P16, P17 and P20 against the isolated Vibrio species

\begin{tabular}{ccccc}
\hline Vibrio host & \multicolumn{5}{c}{ Phage isolates } \\
& P10 & P16 & P17 & P20 \\
V1 & - & - & - & - \\
V 2 & + & - & + & - \\
V 3 & - & - & - & - \\
V 4 & + & - & + & - \\
V 5 & - & - & - & - \\
V 6 & - & - & - & - \\
V 7 & - & - & - & - \\
V 8 & - & - & + & - \\
V 9 & - & - & + & + \\
V 10 & + & - & + & - \\
V 11 & - & - & - & + \\
V 12 & - & - & + & - \\
V 13 & - & - & - & - \\
V 14 & - & - & + & - \\
V 15 & + & - & + & - \\
V 16 & + & + & + & + \\
V 17 & - & - & + & + \\
V 18 & - & - & - & + \\
V 19 & - & - & - & - \\
V 20 & - & - & + & + \\
\hline
\end{tabular}

Fig.2 Electron micrograph of P17

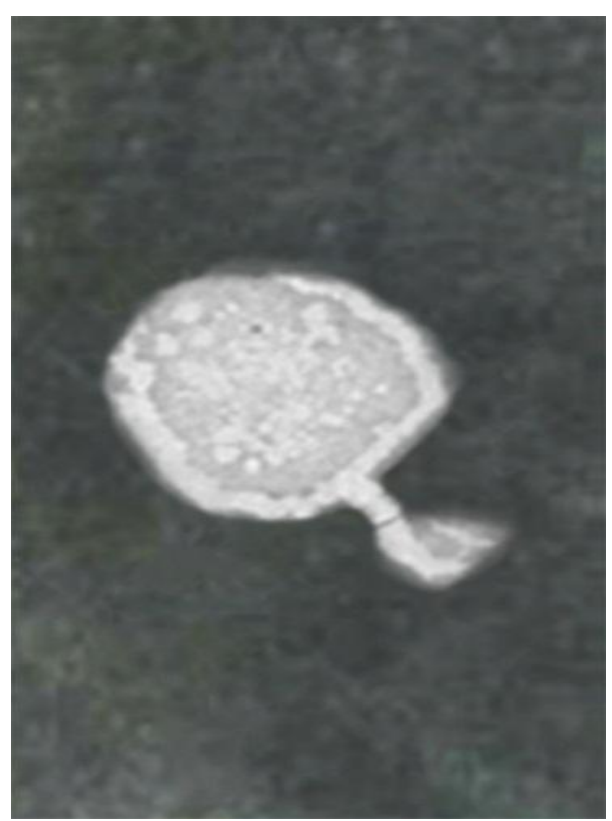


Fig.3 Plaques produced by phage $\mathrm{P} 17$ on $V$. parahaemolyticus host bacterium

Fig.4 Effect of temperature on survival of phage P17. Different letters (a, b,c) indicate significant difference $(p<0.001)$

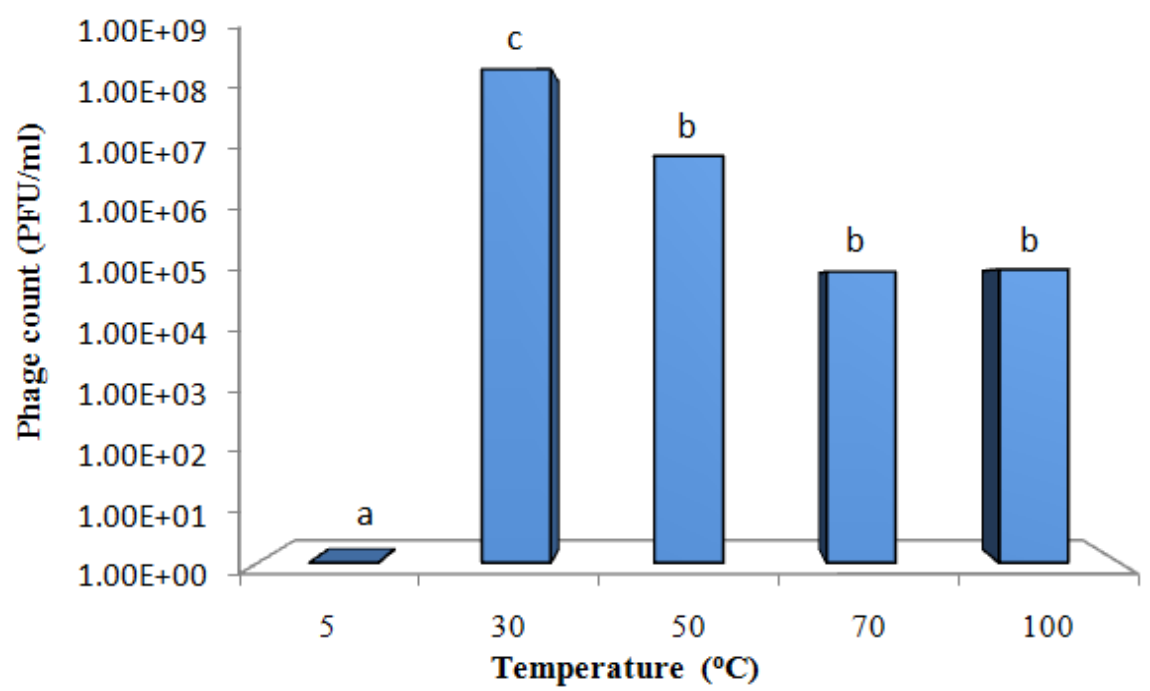

Fig.5 Effect of $\mathrm{pH}$ on survival of phage P17. Different letters (a, b, c) indicate significant difference $(\mathrm{p}<0.001)$

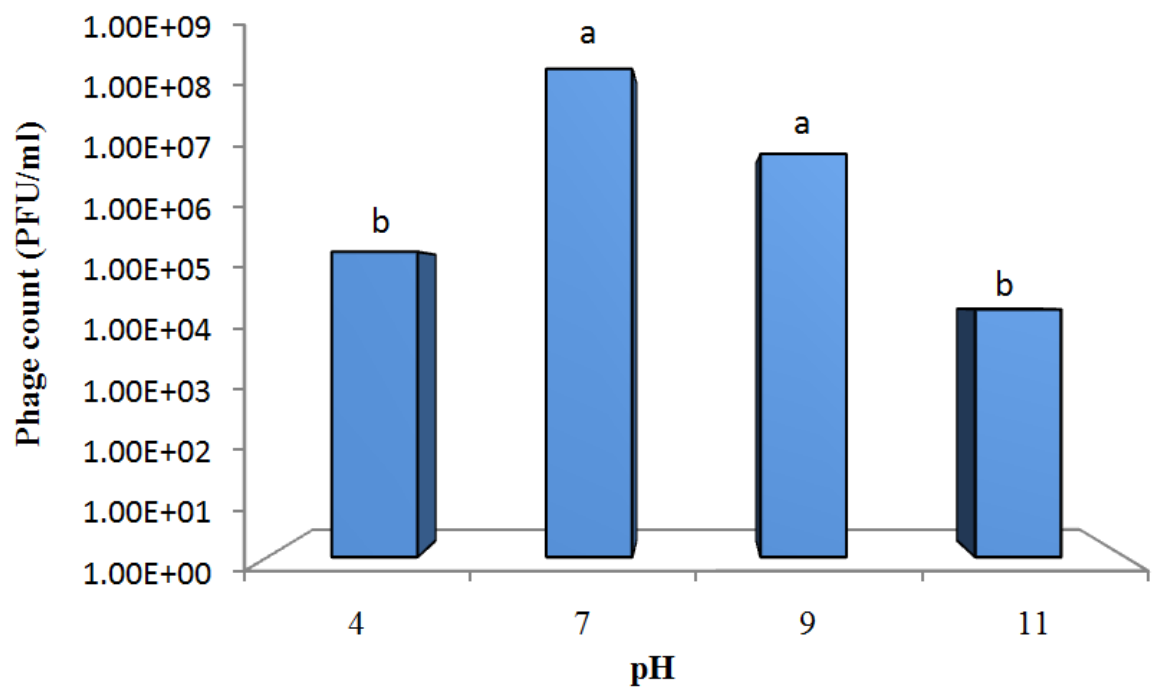


Fig.6 Effect of UV on survival of phage P17. Different letters (a, b, c) indicate significant difference $(\mathrm{p}<0.001)$

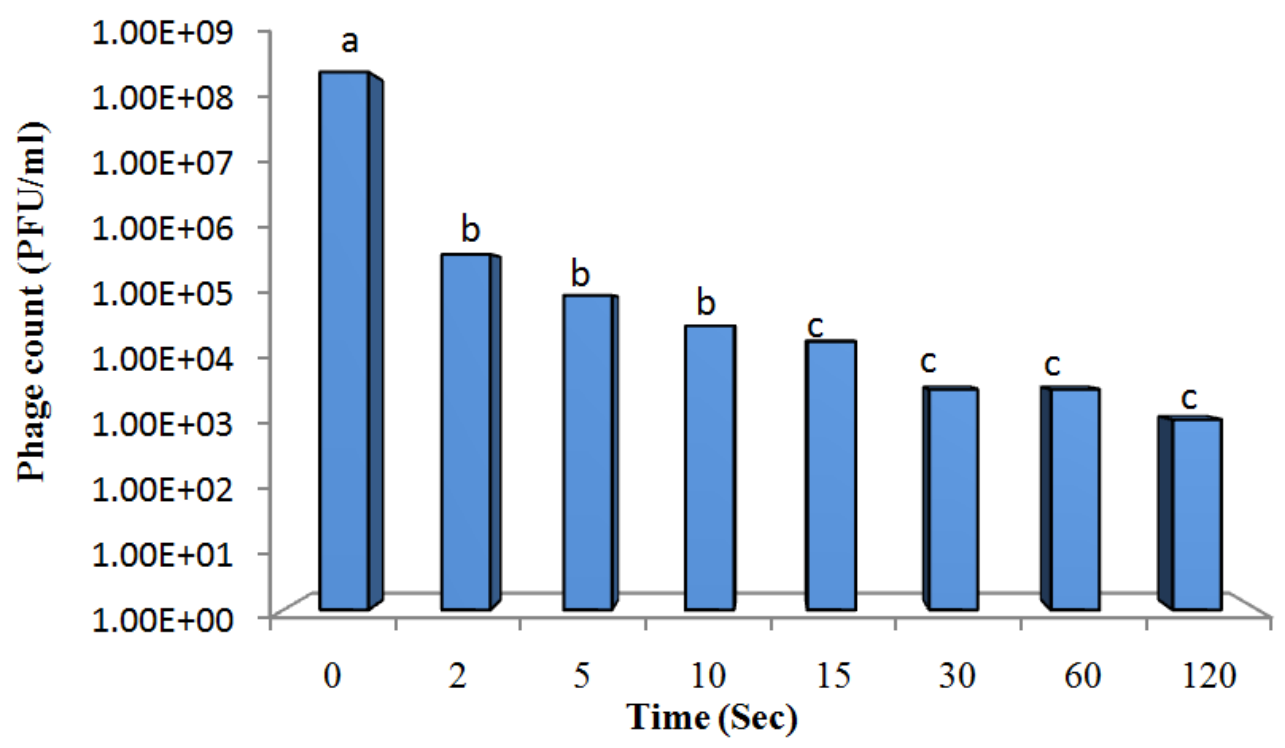

Fig.7 One-step growth curve of phage P17 infecting V. parahaemolyticus.

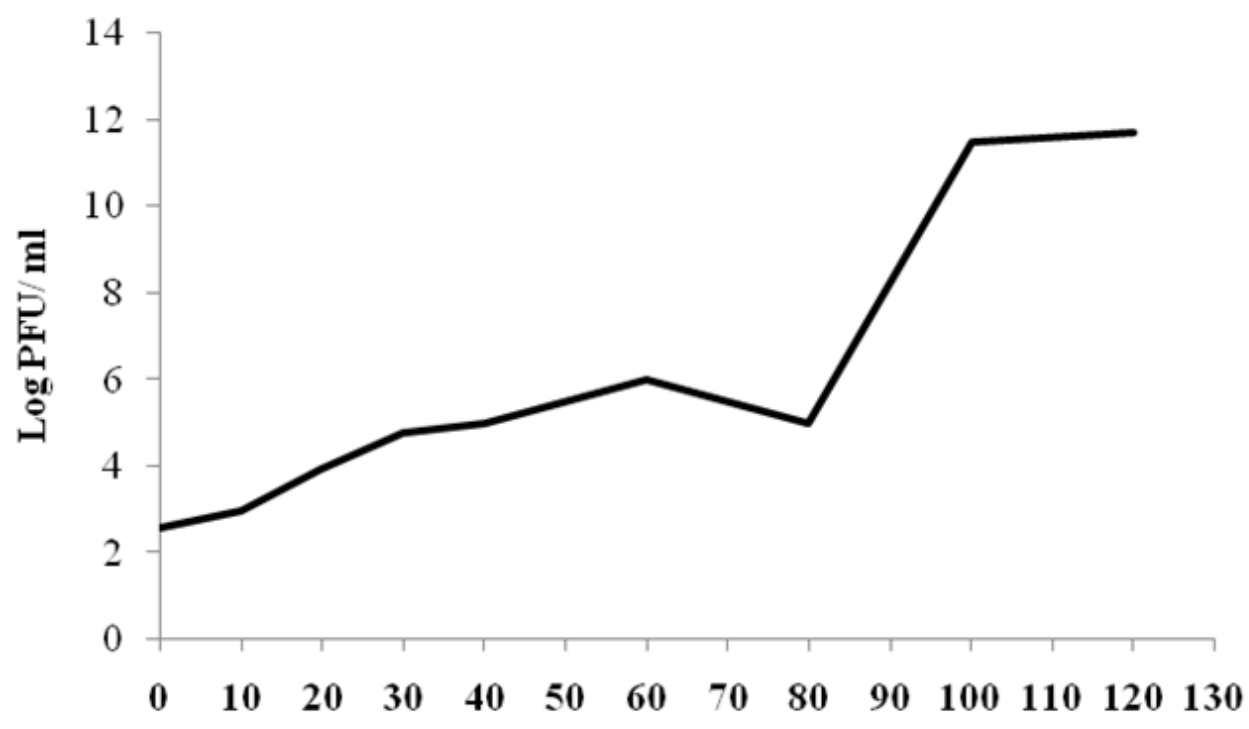

Phage infection time (min) 
Fig.8 In vivo efficiency of phage P17 in elimination of Vibrio spp. in A. salina culture

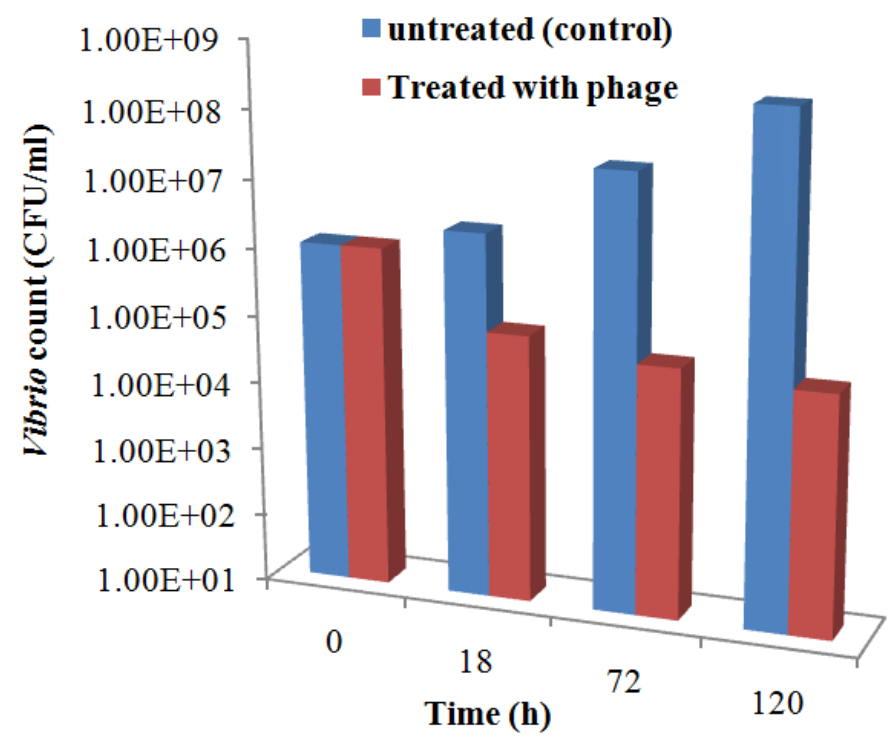

The current experiment aimed at evaluating the in vivo efficiency of $\mathrm{P} 17$ in controlling Vibrio load. To achieve this goal, culture of $A$. salina was dosed with P17 $\left(10^{11} \mathrm{PFU} / \mathrm{ml}\right)$ and counts of Vibrio spp. was monitored at different time intervals for $120 \mathrm{~h}$ (Figure 8). The present study confirmed the possibility of using P17 as biocontrol agent of Vibrio spp. in A. salina culture, where the initial presumptive Vibrio load $\left(11 \times 10^{5} \mathrm{CFU} / \mathrm{ml}\right)$ in phage treated Artemia was decreased by $92 \%$ after $18 \mathrm{~h}$ to reach $\left(8.8 \times 10^{4} \mathrm{CFU} / \mathrm{ml}\right)$ and $95 \%$ after $72 \mathrm{~h}$ to reach $\left(5.5 \times 10^{4} \mathrm{CFU} / \mathrm{ml}\right)$ and the antibacterial effect of P17 was prolonged even after $120 \mathrm{~h}$ with $97 \%$ inhibition of Vibrio load to be eliminated to $\left(3.3 \times 10^{4}\right.$ $\mathrm{CFU} / \mathrm{ml}$ ). The brine shrimp, Artemia is a zooplanktonic organism widely used as live feed. It can be hatched within 24 hours from dormant cysts (batch culture). The efficiency of P17 to eliminate Vibrio load after $18 \mathrm{~h}$ is an advantageous as treatment in the live feeds prior to their introduction in the hatchery system and could effectively reduce the Vibrio load in the larval rearing tanks, which in turn can reduce Vibrio load in fish hatcheries. This finding is supported by a study of Kalatzis et al., (2016) who confirmed that invivo administration of the phage cocktail, $\varphi$ St 2 and $\varphi$ Grn1 on live prey A.salina cultures, led to a $93 \%$ decrease of presumptive Vibrio population after $4 \mathrm{~h}$ of treatment. Pai (2006) isolated five Vibrio phages from a sediment sample collected from the Vembanad estuary, Kochi. Kerala and evaluated their efficiency to prevent the growth of $V$. harveyi in plain seawater and concluded that phages were able to arrest the growth of $V$. harveyi for about $12 \mathrm{~h}$ after which phage resistant forms emerge and begin to dominate. Numerous studies using bacteriophages as treatment agents, verify their applications in many aquaculture systems have been successful against many pathogenic bacteria such as $V$. parahaemolyticus, $\quad$. harveyi, and V.anguillarum (Vinod et al., 2006; Karunasagar et al., 2007; Higuera et al., 2013; Lomelí-Ortega et al., 2014).

In conclusion, the Vibriophage P17 could be promising antibacterial candidate against pathogenic bacteria and can be used as effective alternative to the commercial antibiotics. Future studies are needed to characterize the genome of $\mathrm{P} 17$ and to establish its potential application for Vibrio treatment on large scale. 


\section{References}

APHA, 1998. Standard methods for the examination of water and wastewater, 19th ed. Clesceri, L.S.; Greenberg, A.E. and Eaton (eds), A.D. American Public Health Association, American Water Works Association, and Water Environment Federation, Washington, D.C

Abou Elela, G.M., Ibrahim, H.H.A., El Helow, E. and Sabry, S. 2009a. Abundance and antagonistic interactions among bacterioplankton in Suez Gulf. World Appl. Sci. J, 7(6): 748-755.

Abou-Elela, G.M., El Sersy, N. A., AbdElnaby, H. and Wefky, S. H. 2009b. Distribution and biodiversity of faecal indicators and potentially harmful pathogens in North Delta (Egypt). Aust. J. Bas Appl Sci. 3(4), 3374-3385.

Adams, M. 1959. Bacteriophages. Interscience Publishers, NewYork, NY

Adhya S. and Merril, C. 2006. The road to phage therapy. Nature. 443, 754-755.

Alan A. Zavala-Norzagaray, A. Alonso Aguirre, Jorge Velazquez-Roman, Héctor Flores-Villaseñor, Nidia León-Sicairos, C. P. Ley-Quiñonez, Lucio De Jesús Hernández-Díaz and Adrian CanizalezRoman Isolation, characterization, and antibiotic resistance of Vibrio spp. in sea turtles from Northwestern Mexico. Frontiers Microbiol. 635, 1-10.

Andrews, L.BS. 2004. Strategies to control Vibrios in molluscan shellfish. Food Prot Trends. 24, 70-6.

Basdew, I. H. and M. D. and Laing. 2014. Stress sensitivity assays of bacteriophages associated with Staphylococcus aureus, causal organism of bovine mastitis. African J. Microbiol. Res. 8(2), 200-210.

Børsheim, K Y. 1993. Native marine bacteriophages. FEMS Microbiol Ecol. 102, 141-159.

Brender, R. and Janda, J.M. 1987. Detection, quantification and stability of â-ha emolysin of Aeromonas spp. J. Med. Microbiol. 24, 247-251.
Ceccarelli, D., Hasan, N. A., Huq, A., and Colwell, R. R. 2013. Distribution and dynamics of epidemic and pandemic Vibrio

parahaemolyticus virulence factors. Front. Cell. Infect. Microbiol. 3, 1-9

Chen, P.K., Citarella, R.V., Salazar, O. and Colwell, R.R. 1966. Properties of two marine bacteriophages. J. Bacteriol. 91,1136-1139.

Da Silva, L.V.A. and Janes, M.E. 2005. Effect of temperature, $\mathrm{pH}$, and salt content on the bacteriophage activities against virulent Vibrio vulnificus, attenuated Vibrio vulnificus, or Vibrio parahaemolyticus.. IFT Annual Meeting, $15-20$.

Daniels, N.A., MacKinnon, L., Bishop, R., Altekruse, S., Ray, B., Hammond, R.M., Thompson, S., Wilson, S., Bean, N.H., Griffin, P.M. and Slutsker, L. 2000. Vibrio parahaemolyticus infection in the United States, 1973-1998. J Infect Dis. 181, 1661-1666.

Doss, J., Culbertson, K., Hahn, D., Camacho, J., Barekzi, N. 2017. A Review of phage therapy against bacterial pathogens of aquatic and terrestrial organisms. Viruses. 9(50), 1-10.

Dutta, M. and Ghosh, A.N. 2007. Physicochemical characterization of $\mathrm{El}$ Tor Vibriophage S20. Intervirol. 50, 264272.

Elhadi, N., Radu, S., Chen, C.H. and Nishibuchi, M. 2004. Prevalence of potentially pathogenic Vibrio species in the seafood marketed in Malaysia. J. Food. Microbiol. 67(7), 1469-1475.

EL-Masry, M.H., Khalil, A.I., Hassouna, M.S. and Ibrahim, H.A.H. 2002. In situ and in vitro suppressive effect of agricultural composts and their water extracts on some phytopathogenic fungi. World $\mathrm{J}$. Microbiol. Biotechnol. 18, 551-558.

Freire-Moran, L., Aronsson B., Manz C., Gyssens I. C., So A. D., Monnet D. L., et al., 2011. Critical shortage of new antibiotics in development against multidrug-resistant bacteria time to react 
is now. Drug Resist. Updat. 14, 118-124.

Ganesh,S., Saravan, P., Krishnamurthy, P., Chandrakala, N. and Rajendran, K. 2012. Isolation and identification of Vibrio spp. in diseased Channa punctatus from aquaculture. Ind. J. Geo Mar Sci. 41(2), 159-163.

Han, F., Walker, R. D., Janes, M. E., Prinyawiwatkul, W., and Ge, B. 2007. Antimicrobial susceptibilities of Vibrio parahaemolyticus and Vibrio vulnificus isolates from Louisiana Gulf and retail raw oysters. Appl. Environ. Microbiol. 73, 7096-7098.

Hassan, S.W.M. 2002. Studies on the use of coliphages as indicator of wastewater pollution in Alexandria. MSc. Thesis, Fac. Sci. Alex. Univ.

Hassan, S.W.M. 2011. Isolation and characterization of some bacteriophages and their associated bacteria in sea food: phage-host interaction. Bullet. High Instit. Pub. Heal. 41(4), 403-424.

Higuera, G., Bastías, R., Tsertsvadze, G., Romero, J. and Espejo RT. 2013. Recently discovered Vibrio anguillarum phages can protect against experimentally induced Vibriosis in Atlantic salmon, Salmo salar. Aquaculture. 392-395, 128133.

Ibrahim, W.N., Aznan, A.S., Saari, N.A., Leong, L.K., Musa, N., Razzak, L.A., Danie, M.D., Zainathan, S.C., Din, M.S., Ghaffar, M.A., Musa. N. In-vitro characterization of lytic bacteriophage PhVh6 as potential biocontrol agent against pathogenic Vibrio harveyi. 2017. AACL Bioflux, 10(1), 64-76.

Jiang, S.C., Kellogg, C.A. and Paul, J.H. 1998. Characterization of marine temperate phage-host systems isolated from Mamala Bay, Oahu, Hawaii. Appl. Environ. Microbiol. 64(2), 535-542.

Jun, J.W., Shin, T.H., Kim, J.H., Shin, S.P. Han, j.E., Heo, G.J., De Zoysa, Shin, G.W., Chai, J.Y. and Park, S.C. 2014. Bacteriophage therapy of a Vibrio parahaemolyticus infection caused by a multiple-antibiotic-resistant $\quad \mathrm{O} 3: \mathrm{K} 6$ pandemic clinical strain. J. Infectious Dis. 210,72-80.

Kalatzis, P.G. 2016. Isolation and Characterization of two lytic bacteriophages, $\varphi$ St 2 and $\varphi$ Grn 1 ; Phage therapy application for biological control of Vibrio alginolyticus in aquaculture live feeds. Plos.One. 1-18.

Karunasagar, I., Shivu, M.M., Girisha, S.K., Krohne, G. and Karunasagar, I. 2007. Biocontrol of pathogens in shrimp hatcheries using bacteriophages. Aquaculture. 268, 288-292.

Lal, T.M., Sano, M. and Ransangan, J. 2016. Genome characterization of a novel Vibriophage VpKK5 (Siphoviridae) specific to fish pathogenic strain of Vibrio parahaemolyticus. J. Basic Microbiol. 56, 872-888

Langlet, J., Gaboriaud, F. and Gantzer, C. 2007. Effects of $\mathrm{pH}$ on plaque forming unit counts and aggregation of MS2 bacteriophage. J. App. Microbiol. 103(5), 1632-1638.

Letchumanan, V., Chan, K.G. and Lee, L.H. 2014. Vibrio parahaemolyticus: a review on the pathogenesis, prevalence, and advance molecular identification techniques. Front. Microbiol. 5, 1-13.

Letchumanan, V., Cha, K., Pusparajah, P., Saokaew, S., Duangjai, A., Goh, B., Mutali, N. and Lee, L. 2016. Insights into bacteriophage application in controlling Vibrio Species. Front. Microbiol.

Letchumanan, V., Pusparajah, P., Hern, T., Loh, T., Yin, W. F., Lee, L.-H., et al., 2015. Occurrence and antibiotic resistance of Vibrio parahaemolyticus from shellfish in Selangor, Malaysia. Front. Microbiol. 6, 1-11.

Lin, Y. and Lin, C. 2012. Genome-wide characterization of Vibrio phage $\phi \mathrm{pp} 2$ with unique arrangements of the mob-like genes. Lin. Lin BMC Genomics. 13, 1-14.

Lin Y., Chiu, C.W., Chang, F.Y., Chan-Shing. 2012. Characterization of a new phage, termed A318, which is specific for Vibrio alginolyticus. Lin. Arch. Virol 157, 917926. 
Lomelí-Ortega, C.O., Martínez-Díaz, S.F. Phage therapy against Vibrio parahaemolyticus infection in the white leg shrimp (Litopenaeus vannamei) larvae. 2014. Aquaculture. 434 (2014), 208-211.

Mahbub, K.R., Paul, K.P., Ahmed, M.M., Ahmed, M.M. et al. 2011. Prevalence of VibrioSpp and antibiogram of isolates from shrimp rearing ponds in Bangladesh. J AdvScient Res. 2(4), 74-80.

Manjush, S., Sarita, G.B., Elyas, K.K. and Chandrsekaran, M. 2005. Multiple antibiotic resistances of Vibrio isolates from coastal and brackish water areas. Am J Biochem. 1(4), 193-198

Meaden, S. and Koskella B. 2013. Exploring the risks of phage application in the environment. Front. Microbiol. 4, 1-8.

Nakai, T. and Park S.C. 2002. Bacteriophage therapy of infectious diseases in aquaculture. Res. Microbiol. 153, 13-18.

Noriega-Orozco, L., Acedo-Félix, E., HigueraCiapara, I., Jiménez-Flores, R. and. Cano, R. 2007. Pathogenic and non pathogenic Vibrio species in aquaculture shrimp ponds. 49(3-4), 60- 67.

Pai, S.S. (2006). PH.D. Thesis. Fac.Mar.Sci. Cochin University.

Payet, J.P. and Suttle, C. A. 2014. Viral infection of bacteria and phytoplankton in the Arctic Ocean as viewed through the lens fingerprint analysis. Aquat. Micob. Ecol. 72, 47-61.

Phumkhachorn, P. and Rattanachaikunsopon, P. 2010. Isolation and partial characterization of a bacteriophage infecting the shrimp pathogen Vibrio harveyi. Afr. J. Microbiol. Res. 4(16), 1794-1800.

Pope, W. H., Haase-Pettingell, C. and King, J. 2004. Protein folding failure sets hightemperature limit on growth of Phage P22 in Salmonella enterica Serovar Typhimurium. Appl. Environ. Microbiol. 70(8), 4840-4847.

Raghunath, P. 2014. Roles of thermostable direct hemolysin (TDH) and TDH-related hemolysin (TRH) in Vibrio parahaemolyticus. Front. Microbiol, 5:805.

Rakhuba, D.V., Kolomiets, E.I., Szwajcer Dey, E and Novik, G.I. 2010. Bacteriophage receptors, mechanisms of phage adsorption and penetration into host cell. Pol J Microbiol. 59, 145-155.

Ran, T. and Su, Y.C. 2006. Effects of electrolyzedoxidizing water treatment on reducing Vibrio parahaemolyticus and Vibrio vulnificus in raw oysters. J. Food Microbiol. 69(8), 1829-1834.

Ransangan, J., Imm, M.K.L. Lal, T.M. and Sade, A. 2013. Phenotypic characterization and antibiotic susceptibility of Vibrio spp. isolated from aquaculture waters on the west coast of Sabah, Malaysia. Int. J. Res. Pure. Appl. Microbiol. 3(3), 58-66.

Rao, B.M. and Lalitha, K. V. 2015. Bacteriophage for aquaculture: are they beneficial or inimical. Aquaculture. 437, $146-154$.

Rice, L.B. 2008. Federal funding for the study of antimicrobial resistance in nosocomial pathogens: no ESKAPE. J. Infect. Dis. 197, 1079-1081.

Ruangpan, L. and Kitao, T. 1991. Vibrio bacteria isolated from black tiger shrimp, Penaeus monodon Fabricius. J. Fish dis. 14, 383-388.

Seeley, N.D. and Primrose, S.B. 1982. The isolation of bacteriophages from the environment. J. Appl. Bact. 53, 1-17.

Shrestha, UT., Adhikari, N., Maharjan, R., Banjara, M.R. Rijal, K.R. Basnyat, S.R. and Agrawal, V.P. 2015. Multidrug resistant Vibrio cholerae $\mathrm{O} 1$ from clinical and environmental samples in Kathmandu city. BMC Infectious Diseases. 15:104.

Stenholm, A.R., Dalsgaard, I. and Middelboe, M. 2008. Isolation and characterization of bacteriophages infecting the fish pathogenFlavobacterium psychrophilum. Appl Environ Microbiol. 74, 4070-4078.

$\mathrm{Su}, \mathrm{Y} . \mathrm{C}$ and Liu, C. 2007. Vibrio parahaemolyticus: A concern of seafood safety. Food Microbiol. 24(6), 549-588 
Sun, G., Jinzhou, Xiao' J., Wang, H., Gong' C., Pan, Y., Yan, S. and Wang, Y. 2014. Efficient purification and concentration of viruses from a large body of high turbidity seawater. Methods X. 1, 197-206.

Taj, J., Ling, X., Bing, L.L., Qi, Z.,Taj, T. M., Hassani, Z., Samreen and Yunlin, W. J. Effect of dilution, temperature and $\mathrm{pH}$ on the lysis activity of $\mathrm{T} 4$ phage against E.coli BL 21. 2014. Animal Plant Sci. 24(4), 1252-1255.

Thompson, F.L., Iida, T. and Swings, J. 2004. Biodiversity of Vibrios. Microbiol. Mol. Biol. Rev. 68, 403-431.

Vale, P. F., Sternman, M. and Little, T. J. 2008. Temperature dependent costs of parasitism and maintenance of polymorphism under genotype- by environment interactions. J. Evol. Biol. $21,1418-1427$.

Vinod, M.G., Shiv,u M.M., Umesha, K.R., Rajeeva, B.C., Krohne, G., Karunasagar, I., et al., 2006. Isolation of Vibrio harveyi bacteriophage with a potential for biocontrol of luminous Vibriosis in hatchery environments. Aquaculture. 255, 117-124.

Wiegle, J.J. 1953. Induction of mutations in a bacterial virus. Genetics. Proc. Nat. Acad.
Sci. 39, 628-636.

Wittebole, X., Rock, S. D. and Opal S. M. 2014. A historical overview of bacteriophage therapy as an alternative to antibiotics for the treatment of bacterial pathogens. Virulence. 5, 226-235.

Yen, M., Cairns, L. S., Camilli, A. 2017. A cocktail of three virulent bacteriophages prevents Vibrio cholerae infection in animal models. Nature communicat, 1-7.

Yu, Y., Gong, T., Jost, G., Liu, W., Ye, D. and Luo, Z. 2013. Isolation and characterization of five lytic bacteriophages infecting a Vibrio strain closely related to Vibrio owensi. FEMS Microbiol Lett. 348, 112-119.

Zachary, A. 1978. An ecological study of bacteriophages of Vibrio natriegens. Can J. Microbiol. 24, 321-324.

Zhan, Y., Huang, S., Voget, S., Simon, M. and Chen, F. 2016. A novel roseobacter phage possesses features of podoviruses, siphoviruses, prophages and gene transfer agents. Sci Rep. 6, 30372.

Zukovs, G., Kollar, J., Monteith, HD., Ho, K.W.A. and Ross, S.A. 1986. Disinfection of low quality wastewaters by ultraviolet light irradiation. J. Wat. Pollut. Cont. Fed. 58, 199-206.

\section{How to cite this article:}

Sahar Wefky Mostafa Hassan. 2017. Phenotypic Characterization of Vibrio Species: Application of Indigenous Phages for Biological Control of Vibrio in Aquaculture Live Feeds. Int.J.Curr.Microbiol.App.Sci. 6(6): 2760-2778. doi: https://doi.org/10.20546/ijcmas.2017.606.329 